\title{
WHO ARE WINE TOURISTS? \\ AN EMPIRICAL INVESTIGATION OF SEGMENTS IN SERBIAN WINE TOURISM
}

\author{
Dejan Sekulić1, Aleksandar Petrović2 ${ }^{2}$ Vladimir Dimitrijevic ${ }^{3}$
}

\section{Summary}

This paper aims to investigate who are the wine tourists in Serbia. The research was conducted by using a survey method. Two profile questions were used aimed to identify segments: "Do you consume wine?" and "Have you ever visited some winery in Serbia"? Of a total number, 152 completed questionnaires were received. According to the research results, two segments of wine tourists were defined: active and potential. The active wine tourists are persons who consume wine and so far have visited some wineries and participated in wine tourism. The potential wine tourists also consume wine, but haven't visited any winery in Serbia so far. Motives for inclusion in wine tourism of both these groups are similar, while the active wine tourists have shown greater readiness to revisit the favourite winery and participate actively in wine tourism in future period in regard to the potential ones.

Keywords: wine tourists, segmentation, motivation, behavioral intention, barriers.

JEL: D12, M21, Q13, L83

\section{Introduction}

Modern tourism is based on shorter, but frequent visits of tourists to the specific destinations, in order to reveal new localities and attractions. Tourists are more interested in adventures and experiences during the trip, which affects the emergence of new tourism products and new forms of tourism.

1 Dejan Sekulić, PhD, Assistant, University of Kragujevac, Faculty of Hotel Management and Tourism in Vrnjačka Banja, Vojvođanska bb, 36210 Vrnjačka Banja, Serbia, Phone: +38162602902, E-mail: dejan.sekulic@kg.ac.rs

2 Aleksandar Petrović, MA, PhD candidate, University of Kragujevac, Faculty of Hotel Management and Tourism in Vrnjačka Banja, Vojvođanska bb, 36210 Vrnjačka Banja, Serbia, Phone: +381604553366, E-mail: acapetrovic86@yahoo.com

3 Vladimir Dimitrijevic, MA, Public Enterprise "Pošta Srbije", Balkanska 27, 11000 Belgrade, Serbia, Phone: +381112686570; E-mail: v_dimitrijevic@yahoo.com

EP 2017 (64) 4 (1571-1582) 
These modern forms of tourism comprise sport and recreation, culinary delights and gastronomy, culture and customs and can be marked as the specific forms of tourism. Interest in the specific forms of tourism has increased in recent years, and tourists who participate in them spend more money, travel more often and practice more activities than other tourists (MacKay et al., 2002).

Activities related to wine and the desire of tourists to visit wine destinations and wine cellars, and to get acquainted with the wine production method, wine culture and customs, are getting a special interest in the world within the specific forms of tourism, which all affects the development of wine tourism. In the 2004 in France, 7.5 million wine tourists were registered, of which 2.5 million was foreigners. In Italy 4 million wine tourists were registered, in the USA more than 4 million only in Napa Valley, while in Spain in the year 2008 was recorded 1 million wine tourists. The most of wineries open for tourist visits are located in Australia (80\%) and in Germany (60\%) (Marzo-Navarro, Pedraja-Iglesias, 2010). In the USA, wine toutists spend around \$ 3 billion a year on visits to wine-growing regions (Bonn et al., 2016).

In general, wine tourism can be defined as visits to wineries, to vineyards, and to wine and grape festivals, where experiencing the attributes of a wine or of production regions constitutes the main reason for a visit. Thus, a wine tourist can be any person who gets involved in appreciating elements that are related to wine while visiting a production region (O'Neill, Palmer, 2004). Wine tourists are fundamentally motivated by the esthetic experience or the enrichment through unique environs such as the wine country. Tasting and purchasing wine have been identified as motivations for visiting a particular region. While tourists may gaze at the winescape (esthetic experience), they may also actively engage in wine country recreation (escapist experience), abundant in the natural, rural setting of wine regions (Quadri-Felitti, Fiore, 2016).

Wine tourism, as the specific form of tourism in Serbia is in its infancy. Wineries in Serbia don't have precise data regarding a number of tourists who visit them. That is why these problems point out to the significance of research in the field of wine tourism, motivation of tourists to be included in this form of tourism, as well as defining the wine tourists segments.

The basic research problem in this paper is the definition of wine tourists, as well as the identification of differences in motives, intentions and behavior among them. Based on the review of previous research in domestic and foreign literature, a research model has been developed, which includes three groups of questions related to: motives for participation in wine tourism, behavioral intention and barriers.

An empirical research was conducted to identify wine tourists. Two profile questions, "Do you consume wine" and "Have you ever visited some winery in Serbia", were used. The first profile question aims to identify respondents who consume wine in relation to non-consumers. Respondents who are marked as non-consumers are not included in further research. Only those who are wine consumers remain in the sample. On the basis of the second profile question, the segmentation of wine tourists was carried out 
in two groups. The first group consists of those who consume wine and take part in wine tourism. This group is named as "active wine tourists". The second group consists of respondents who consume wine, but have not yet visited a wine cellar or participated in wine tourism. That is why this group is marked as "potential wine tourists".

Using the descriptive statistical analysis, the values of the arithmetic means of independent variables in the model are determined. By calculating the Cronbach alpha coefficient, the reliability of the model was estimated. Using the t-test, differences in the average marks of the defined variables were calculated for these two groups of respondents.

In domestic literature there is very little research in this field and these works are primarily theoretical. The significance of the research in this paper, in addition to theoretical contribution, is reflected in the empirical verification of the introduced model in order to identify the most important motives that influence the inclusion of wine consumers in wine tourism, as well as determining the difference between the defined segments of wine tourists.

\section{Research methodology}

The survey method was used in this research for collecting the primary data. The questionnaire consists of three groups of questions, which are drafted according to the relevant researches (Bruwer, 2003; Bruwer, 2004; Brown et al., 2006; MarzoNavarro, Pedraja-Iglesias, 2009; Alonso, 2009; Marzo-Navarro, Pedraja-Iglesias, 2010; Grybovych, Lankford, Lankford, 2013, Sekulić et al. 2016).

The first group of questions encloses 12 assertions, which refer on tourists motives to take part in wine tourism. Respondents were rating these assertions on a scale from 1 to 7, where 1 meant "absolutely irrelevant", and 7 meant "absolutely relevant".

The second group of questions encloses 2 observations concerning the intention of tourists to visit wine destinations and be active participants in wine tourism. The respondents appraise these assertions on a scale from 1 (I absolutely disagree) to 7 (I absolutely agree).

The third group of questions was defined by using 3 assertions, which refer to limitations for taking part in wine tourism. These limitations refer to time necessary for taking part in wine tourism, remoteness and inaccessibility of wine tourism destinations, as well as the wine tourism costs.

Besides these questions, the questionnaire enclosed also the questions regarding the demographic characteristics of respondents (gender, age and education), as well as two profile questions: "do you consume wine?" and "have you visited some winery in Serbia so far"? 


\section{Segmentation of wine tourists}

There are numerous researches in the literature, which tend to define the wine tourists. Therefore, there is no unique stereotype of a wine tourist, as well as no unique definition of who he really is. Number of these tourists, in countries with the developed wine tourism, ranges from 5 to 30 percentage of the total number of tourists. These are "casual" tourists, who visit wineries in order to taste wine. In addition, we can also find the "sophisticated drinkers", who are interested in getting additional information on wine and its production as well, besides wine tasting. Wineries consider that around 5\% of tourists make this group, and their number depends on a winery reputation and a wine manufacturer (Charters, Ali-Knight, 2002).

In the study conducted in Italy (1996), Corigliano was identified four groups of wine tourists. The Professional: persons between 30-45 years of age, who are good wine connoisseurs and its production, interested in trying something new and ready to invest time and energy in research. The Impassioned Neophyte: persons between 25-30 years of age, they like wine, enjoy food, like to travel in company, like to find out something new and make new friendships. The Hanger: persons between 40-45 years of age, richer, interested in wine because they think that the proficiency in wine differentiates them from other people, but they know only basic things about wine, they are easy to impress, sometimes ask for a discount. The Drunker: persons between 50-60 years of age, they visit wineries in groups on Sundays, consider them as an alternative to a bar, they drink fast and ask for more, buy wine in balloons.

In conversation with wineries in New Zealand, Hall (1996) was identified three groups of wine tourists: the "wine lovers", the "wine interested" and "curious tourists". Dodd and Bigotte (1997) were studying visitors to the wineries in Texas and were defined two segments based on the respondents' age and their income. The first group was made of older tourists with higher income in regard to the second group.

Di-Gregorio and Licari (2006) was identifying three segments in their research conducted in South Italy: Opinion leaders: passionate about wine and write for wine magazines. Wine tourists: their goal is to increase knowledge on wine and buy a bottle of wine in the winery. Occasional tourists: they are more interested in vacation and visit to restaurants than in wine.

Browen et al., (2006) were defined four segments: Demanding gourmet: male, selfemployed, takes part in wine tourism, visits wineries and makes acquaintances in them, visits good restaurants. Hedonic aficionados: a man who often drinks wine. Prudent enthusiast: female, employed, consumes wine less than the previous two groups. Functional differentiator: retired woman.

Galloway et al., (2008) were singled out two groups of wine tourists: Higher sensation seekers: male, has high incomes, buys more bottles of wine per month, visits several wineries annually, uses the internet to get information about wineries, takes part in several activities during the visit to wineries and wine destinations. Lower sensation seekers: female with less expressed participation in activities in regard to the first group. 
Brunner and Synergist (2011) were identified six segments of wine consumers in their research conducted in Switzerland: the price-conscious wine consumer; the involved, knowledgeable wine consumer; the image-oriented wine consumer; the indifferent wine consumer; the basic wine consumer; and the enjoyment-oriented, social wine consumer.

In the research conducted in Germany, Koch, et al., (2013) were determined that person between 35-45 and 45-60 years of age are two most suitable groups for wine tourism. These two groups have higher incomes in regard to younger respondents and show more interest in wine. Only $21 \%$ of respondents between 18-25 and 25-35 years of age are worth targeting, while $19 \%$ of persons older than 60 years have shown interest in taking part in wine tourism.

Salai, et al., (2013) define three wine consumer segments according to the frequency of consumption: consumers who consume wine regularly, consumers who consume wine rarely and consumers determined by habit.

Olsen et al., (2015) were identified three segments of wine consumers in the research conducted in the USA: high variety-seeking consumers, moderate variety-seeking and variety avoiders. High variety seekers are younger, hold values favouring stimulation and tolerance of risk, pay more for wine, purchase wine in more locations, prefer more varietals and consider themselves more wine knowledgeable and involved than the other two segments.

\section{Results and Discussion}

Of the total number of sent questionnaires, 160 completed questionnaires were received. Eight respondents (5\%) said that they don't like to drink wine, and therefore they were not taken into further consideration. Only those respondents who consume wine remained in the sample (152).

Table 1. Demographic characteristics of respondents

\begin{tabular}{|l|c|c|}
\hline Demographic characteristics & Frequency & Share (\%) \\
\hline Gender & & \\
\hline Male & 78 & $51.3 \%$ \\
\hline Female & 74 & $48.7 \%$ \\
\hline Age & & \\
\hline Up to 25 & 10 & $6.6 \%$ \\
\hline $25-34$ & 62 & $40.8 \%$ \\
\hline $35-44$ & 66 & $43.4 \%$ \\
\hline $45-54$ & 11 & $7.2 \%$ \\
\hline $55+$ & 3 & $2.0 \%$ \\
\hline Education & & \\
\hline Secondary school & 13 & $8.6 \%$ \\
\hline College & 40 & $26.3 \%$ \\
\hline
\end{tabular}




\begin{tabular}{|l|c|c|}
\hline Demographic characteristics & Frequency & Share (\%) \\
\hline University & 99 & $65.1 \%$ \\
\hline Visit to wineries & & \\
\hline Yes & 90 & $59.2 \%$ \\
\hline No & 62 & $40.8 \%$ \\
\hline
\end{tabular}

Source: Authors' research

Taking into consideration the second segmentation criterion, which refers on the visit to wineries in Serbia, two groups of respondents were identified. The first group makes 90 respondents, who consume wine and have visited some winery in Serbia (59.2\%). The second group of 62 respondents makes persons who consume wine, but still haven't visited any winery in Serbia (40.8\%).

The first group will be called the "active "wine tourists, while it is consisted of the respondents who drink wine and have visited some winery so far and have participated in wine tourism. On the other hand, we can find the respondents who drink wine as well, but still haven't visited any winery in Serbia. These tourists will be called the "potential" wine tourists.

Table 2. Demographic characteristics of segments

\begin{tabular}{|l|c|c|c|c|}
\hline \multicolumn{1}{|c|}{$\begin{array}{c}\text { Demographic } \\
\text { characteristics }\end{array}$} & Frequency & $\mathbf{( \% )}$ & Frequency & (\%) \\
\hline & & & & \\
\hline Gender & 55 & $61.1 \%$ & 23 & $37.1 \%$ \\
\hline Male & 35 & $38.9 \%$ & 39 & $62.9 \%$ \\
\hline Female & & & & \\
\hline Age & 4 & $4.4 \%$ & 6 & $9.7 \%$ \\
\hline Up to 25 & 30 & $33.3 \%$ & 32 & $51.6 \%$ \\
\hline $25-34$ & 46 & $51.1 \%$ & 20 & $32.3 \%$ \\
\hline $35-44$ & 8 & $8.9 \%$ & 3 & $4.8 \%$ \\
\hline $45-54$ & 2 & $2.2 \%$ & 1 & $1.6 \%$ \\
\hline $55+$ & & & & \\
\hline Education & 9 & $10.0 \%$ & 2 & $3.2 \%$ \\
\hline Secondary school & 22 & $24.4 \%$ & 9 & $14.5 \%$ \\
\hline College & 59 & $65.6 \%$ & 51 & $82.3 \%$ \\
\hline University & & &
\end{tabular}

Source: Authors' research

An active wine tourist is a male, between 35-44 years of age, with a university degree. On the other hand, a potential wine tourist is a female, between 25-34 years of age, also with a university degree. 
Table 3. Differences in segment estimates

\begin{tabular}{|l|c|c|c|c|}
\hline Motives for participation in wine tourism & $\begin{array}{c}\text { Active } \\
\text { (Mean) }\end{array}$ & $\begin{array}{c}\text { Potential } \\
\text { (Mean) }\end{array}$ & t-value & Sig. \\
\hline Visit to wineries & 6.28 & 5.72 & 1.724 & 0.091 \\
\hline Wine tasting & 6.43 & 6.00 & 1.441 & 0.155 \\
\hline Purchasing wine & 5.21 & 4.91 & 0.796 & 0.430 \\
\hline Trying different types of wines & 6.26 & 5.78 & 1.614 & 0.111 \\
\hline Getting to know wine manufacturers & 5.81 & 5.13 & 1.925 & 0.058 \\
\hline $\begin{array}{l}\text { Getting information on wine and its } \\
\text { production }\end{array}$ & 6.21 & 5.50 & 2.229 & $0.029 * *$ \\
\hline Taking part in wine production & 4.23 & 3.53 & 1,813 & 0,074 \\
\hline Tasting local gastronomic specialties & 5.62 & 5.03 & 1,750 & 0,086 \\
\hline $\begin{array}{l}\text { Shops with the local agricultural and } \\
\text { handicraft products }\end{array}$ & 5.06 & 4.44 & 1.519 & 0.134 \\
\hline Opportunities for recreation and vacation & 5.70 & 5.09 & 1.811 & 0.076 \\
\hline Meeting people with similar interests & 5.19 & 4.56 & 1.863 & 0.066 \\
\hline $\begin{array}{l}\text { Trip organization (transport, } \\
\text { accommodation, activities) }\end{array}$ & 5.91 & 5.34 & 1.679 & 0.100 \\
\hline Behavioral intention & $\begin{array}{c}\text { Active } \\
\text { (Mean) }\end{array}$ & $\begin{array}{c}\text { Potential } \\
\text { (Mean) }\end{array}$ & t-value & Sig. \\
\hline $\begin{array}{l}\text { I would gladly visit a winery in which } \\
\text { manufactures wine I like to drink }\end{array}$ & 6.64 & 6.03 & 2.436 & $0.019 * *$ \\
\hline $\begin{array}{l}\text { I would take part in wine tourism in future } \\
\text { period }\end{array}$ & 6.17 & 5.28 & 3.074 & $0.003 * *$ \\
\hline Barriers & $\begin{array}{c}\text { Active } \\
\text { (Mean) }\end{array}$ & $\begin{array}{c}\text { Potential } \\
\text { (Mean) }\end{array}$ & t-value & Sig. \\
\hline High costs of wine tourism & 4.68 & 4.63 & 0.180 & 0.858 \\
\hline $\begin{array}{l}\text { Wine destinations in Serbia are remote and } \\
\text { inaccessable }\end{array}$ & 3.64 & 3.88 & -0.616 & 0.540 \\
\hline It takes a lot of time for wine tourism & 3.57 & 3.72 & -0.419 & 0.677 \\
\hline
\end{tabular}

Source: Authors' research

The active wine tourists have rated the following assertions with the highest ratings, which point out to the basic motives for taking part in wine tourism: wine tasting (6.43), visit to wineries (6.28), trying different wines (6.28), getting information about wine and its production (6.21). They rated with something worse grades: participation in wine production (4.23), shops (5.06) and meeting people (5.19). The active wine tourists would gladly visit wineries (6.64); while on the other hand, they consider that the necessary time (3.57) and the remoteness of wine destination (3.64) are not significant barriers for taking part in wine tourism. 
The potential wine tourists have rated with the highest grades the following motives for the inclusion in wine tourism: wine (6.03), trying various wines (5.78), visit to wineries (5.72), getting information about wine and its production (5.50). They rated with worse grades those assertions that refer to: participation in wine production (3.53), the existence of shops (4.44) and meeting people (4.56). Similar to the active ones, but worse rated, the potential wine tourists would gladly visit the winery that manufactures wine they consumed (6.03). The potential wine tourists don't consider that it takes a lot of time for wine tourism (3.72), as well as that they don't consider the wine destinations as distant (3.88).

Table 4. Basic characteristics of the active and potential wine tourists

\begin{tabular}{|c|c|}
\hline $\begin{array}{l}\text { Type of wine } \\
\text { tourists }\end{array}$ & Characteristics \\
\hline \multirow{6}{*}{$\begin{array}{c}\text { Active Wine } \\
\text { Tourists }\end{array}$} & Male \\
\hline & $35-44$ years of age \\
\hline & University education \\
\hline & $\begin{array}{l}\text { Primary motives: wine tasting, visit wineries, trying wines, getting information } \\
\text { about wine and its production. }\end{array}$ \\
\hline & $\begin{array}{l}\text { Secondary motives: taking part in production, interest in local shops, meeting } \\
\text { people. } \\
\text { They are more willing to visit a winery that produces a favourite wine and take } \\
\text { part in wine tourism in regard to the potential wine tourists }\end{array}$ \\
\hline & $\begin{array}{l}\text { Barriers: time and remoteness are less significant in regard to the potential tourists } \\
\text { in order to take part in wine tourism }\end{array}$ \\
\hline \multirow{7}{*}{$\begin{array}{l}\text { Potential Wine } \\
\text { Tourists }\end{array}$} & Female \\
\hline & $25-34$ years of age \\
\hline & Univeristy education \\
\hline & Primary motives: wine tasting, trying wines, visit to wineries \\
\hline & $\begin{array}{l}\text { Secondary motives: taking part in production, interest in local shops, meeting } \\
\text { people. }\end{array}$ \\
\hline & $\begin{array}{l}\text { They are less willing to visit a winery that produces a favourite wine and take part } \\
\text { in wine tourism in regard to the active wine tourists }\end{array}$ \\
\hline & $\begin{array}{l}\text { Barriers: time and remoteness are more significant in regard to the active tourists in } \\
\text { order to take part in wine tourism }\end{array}$ \\
\hline
\end{tabular}

Source: Authors' research

Differences regarding the assertions which refer to the motives of tourists to take part in wine tourism were established by using a t-test. Statistically significant difference appears concerning the assertion on getting information on wine and its production. The active tourists have rated this assertion with an average grade of 6.21, while the potential tourists have rated with $5.50(\mathrm{t}=2.229, \mathrm{p}=0.029<0.05)$, so there have been the statistically important difference in the views of these two groups of respondents. In other words, the active tourists have expressed the greater motivation to learn something about wine and its production, i.e. the greater readiness to educate in regard to the potential wine tourists. 
The statistically important differences in the attitudes of respondents occur concerning the assertions, which describe future behaviour of wine tourists. The active tourists have shown higher interest in visiting the winery that manufactures wine they consume in regard to the potential wine tourists $(\mathrm{t}=2.436, \mathrm{p}=0.019<0.05)$, as well as the greater readiness to take part in wine tourism in time to come $(\mathrm{t}=3.074, \mathrm{p}=0.003<0.05)$.

\section{Conclusion}

Wine tourism in Serbia is in its infancy, but with great potential for development. Subsidies for vineyards, production and processing of wine have influenced the increase in the number of small winery in Serbia for the last ten years. Domestic winemakers are interested in engaging in this form of tourism. It is therefore very important to get an answer to the question "who are wine tourists". The answer to this question will help marketers and winemakers to identify wine tourists, as well as, similarities and differences between different segments. This will enable the creation of an adequate marketing strategies in order to attract more wine tourists and generate more significant revenues.

In this regard, empirical research was conducted with the aim of defining wine tourists and identifying similarities and differences between certain segments. The empirical research results show that the primary motives for taking part in wine tourism for both groups of the active wine tourists (they consume wine and take part in wine tourism) and the potential wine tourists (they consume wine, but haven't participated in wine tourism so far) are the same: wine tasting, visit to wineries and trying different wines.

Secondary motives are also very similar: taking part in wine production, the local shops and meeting people. There can be noticed that the active tourists have rated the defined claims with higher grades in regard to the potential tourists, i.e. they have been more motivated for taking part in wine tourism. The most important difference in these two wine tourists groups' motives is in a fact that the active tourists are more motivated to learn more on wine and its production in regard to the potential wine tourists.

As far as future behaviour of wine tourists is concerned, the best rated claim for both groups was the intention to visit a winery that manufactures wine they consumed. This is important concerning future action and driving force as for the active, as well as for the potential tourists.

On the other hand, the obstacles for taking part in wine tourism, which refer on time, remoteness and costs, are rated low. The negative values of t-test were noticeable here, i.e. the obstacles were related to the destination remoteness, and time necessary for taking part in wine tourism was more significant for the potential wine tourists in regard to the active wine tourists.

The active wine tourists have shown greater readiness to revisit a favourite winery and participate actively in wine tourism in the future. On the other hand, the potential wine tourists showed less readiness to visit wineries and for wine tourism. These results point out to the necessity of using the appropriate marketing tools, aiming to motivate 
the potential tourist to take part in wine tourism and their conversion from the potential tourists into the active wine tourists. Realisation of this goal is possible considering that the potential tourists find the barriers (time, remoteness, and money) are not a significant obstacle for participating in wine tourism.

The significance of this research is reflected in the empirical verification of the introduced model conceived on the basis of relevant researchs in the literature. In domestic literature there are limited number of papers in this field or they are primarily of theoretical character. The limitation of this research refers to the size of the sample. In future research it is necessary to include a large number of respondents. Also, this research could be linked to the research of the attitudes of wine producers regarding wine tourism, their intention and desire to connect at regional and national level in order to promot and develop wine tourism.

\section{References}

1. Alonso, A. (2009): Are travellers interested in wine tourism in New Zealand, International Journal of Culture, Tourism and Hospitality Research, Vol. 3, No. 1, pp. 13-24.

2. Bonn, M., Cho, M., Lee, J.J., Kim, H.J. (2016): A multilevel analysis of the effects of wine destination attributes on travel constraints and revisit intention, International Journal of Contemporary Hospitality Management, Vol. 28, No. 11, pp.2399-2421.

3. Brown, G.P., Havitz, M.E., Getz, D. (2006): Relationship between wine involvement and wine related travel, Journal of Travel \& Tourism Marketing, Vol. 2, No. 1, pp. 31-46.

4. Brown, G.P., Havitz, M.E., Getz, D. (2006): Relationship between wine involvement and wine related travel, Journal of Travel \& Tourism Marketing, Vol. 2, No. 1, pp. 31-46.

5. Brunner, T., Siegrist, M. (2011): A consumer-oriented segmentation study in the Swiss wine market, British Food Journal, Vol. 113, No. 3, pp. 353-373.

6. Bruwer, J. (2003): South African wine routes: some perspectives on the wine tourism industry's structural dimensions and wine tourism product, Tourism Management, Vol. 24, No. 4, pp. 423-435.

7. Bruwer, J. (2004): Wine Tourism Behaviour in the Context of a Motivational Framework for Wine Regions and Cellar Doors, Journal of Wine Research, Vol. 15, No. 1, pp. 25-35,

8. Charters, S., Ali-Knight, J. (2002): Who is the wine tourist?, Tourism Management, Vol. 23, No. 3, pp. 311-319.

9. Corigliano, M.A. (1996): Caratteristiche della domanda strategie di offerta e aspetti territoriali e ambientali, Franco Angeli, Milano, Italy.

10. Di-Gregorio, D., Licari, E. (2006): Rural development and wine tourism in 
Sourthern Italy, Proceedings of 46th Congress of the European Regional Science Association, Volos, Greece, pp. 1-26.

11. Dodd, T. Bigotte, V. (1997): Perceptual differences among visitor groups to wineries, Journal of Travel Research, Vol. 35, No. 3, pp. 46-51.

12. Galloway, G., Mitchell, R., Getz, D., Crouch, G. Ong, B. (2008): Sensation seeking and the prediction of attitudes and behaviours of wine tourists, Tourism Management, Vol. 29, No.5, pp. 950-966.

13. Grybovych, O., Lankford, J., Lankford, S. (2013): Motivations of wine travelers in rural Northeast Iowa. International Journal of Wine Business Research, Vol. 25, No. 4, pp. 285-309.

14. Hair, F. J., Black, C. W., Babin, J. B., Anderson, E. R. (2013): Multivariate Data Analysis (ISBN 1292035110). Pearson Education Limited, Harlow.

15. Hall, C.M. (1996): Wine tourism in New Zealand, Proceedings of Tourism Down Under II: A Tourism Research Conference, University of Otago. http://www-sre. wu.ac.at/ersa/ersaconfs/ersa06/papers/626.pdf

16. Koch, J., Martin, A., Nash, R. (2013): Overview of perceptions of German wine tourism from the winery perspective, International Journal of Wine Business Research, Vol. 25, No. 1, pp. 50-74.

17. MacKay, K., Andereck, K., Vogt, C. (2002): Understanding vacationing motorist niche markets, Journal of Travel Research, Vol. 40, No. 4, pp. 356-363.

18. Marzo-Navarro, M., Pedraja-Iglesias, M. (2009): Wine tourism development from the perspective of the potential tourist in Spain, International Journal of Contemporary Hospitality Management, Vol. 21, No. 7, pp. 816-835.

19. Marzo-Navarro, M., Pedraja-Iglesias, M. (2010): Are there different profiles of wine tourists? An initial approach, International Journal of Wine Business Research, Vol. 22, No. 4, pp. 349-361.

20. O'Neill, M., Palmer, A. (2004): Wine production and tourism: adding service to a perfect partnership, Cornell Hotel and Restaurant Administration Quarterly, Vol. 45, No. 3, pp. 269-284.

21. Olsen, J., Atkin, T., Thach, L., Cuellar, S. (2015): Variety seeking by wine consumers in the southern states of the US, International Journal of Wine Business Research, Vol. 27, No. 4, pp. 260-280.

22. Quadri-Felitti, D., Fiore, M.A. (2016): Wine tourism suppliers' and visitors' experiential priorities, International Journal of Contemporary Hospitality Management, Vol. 28, No.2, pp.397-417.

23. Salai, S., Gašović, M, Čelić, M. (2013): Marketing Research into Wine Consumption Determinants in Vojvodina, Marketing, Vol. 44, No. 2, pp. 103-114.

24. Sekulić, D., Mandarić, M., Milovanović, V. (2016): Motivation of travelers for participation in wine tourism in Serbia, Economics of Agriculture, Vol. 63, No. 4, pp. 1237-1252.

EP 2017 (64) 4 (1571-1582) 


\title{
KO SU VINSKI TURISTI? \\ EMPIRIJSKO ISTRAŽIVANJE SEGMENATA U VINSKOM TURIZMU U SRBIJI
}

\author{
Dejan Sekulić, Aleksandar Petrovićs ${ }^{5}$,Vladimir Petrović ${ }^{6}$
}

\section{Rezime}

Cilj ovog rada je da istraži ko su vinski turisti u Srbiji. Istraživanje je sprovedeno korišćenjem anketnog metoda. U cilju identifikacije segmenata korišćenja su dva profilna pitanja: "da li konzumirate vino" $i$ "da li ste do sada posetili neku vinariju u Srbiji”. Od ukupnog broja pristiglo je 152 potpuno popunjena upitnika. Na osnovu rezultata istraživanja definisana su dva segmenta vinskih turista: aktivni i potencijalni. Aktivni vinski turisti su osobe koji konzumiraju vino i do sada su posetili neku vinariji $i$ učestvovali u vinskom turizmu. Potencijalni vinski turisti takođe konzumiraju vino, ali nisu do sada posetili neku vinariju u Srbiji. Motivi za uključivanje u vinski turizam obe grupe su slični, dok aktivni vinski turisti su pokazali veću spremnost da ponovo posete omiljenu vinariju i aktivno učestvuju u vinskom turizmu u budućem periodu u odnosu na potencijalne.

Ključne reči: vinski turizam, segmentacija, motivacija, namera posete, barijere.

JEL: D12, M21, Q13, L83

4 Dr Dejan Sekulić, Asistent, Univerzitet u Kragujevcu, Fakultet za hotelijerstvo i turizam u Vrnjačkoj Banji, Vojvođanska bb, 36210 Vrnjačka Banja, Srbija, Tel. +38162602902, E-mejl: dejan.sekulic@kg.ac.rs

5 MSc Aleksandar Petrović, doktorant, Univerzitet u Kragujevcu, Fakultet za hotelijerstvo i turizam u Vrnjačkoj Banji, Vojvođanska bb, 36210 Vrnjačka Banja, Srbija, Tel. +381604553366, E-mejl: acapetrovic86@yahoo.com

6 Mr Vladimir Dimitrijević, Javno preduzeće „Pošta Srbije“, Balkanska 27, 11000 Beograd, Srbija, Tel. +381112686570;E-mejl: v_dimitrijevic@yahoo.com 
ECONOMICS OF

AGRICULTURE

\section{CONTENT}

1. Adriana Radosavac, Desimir Knežević

ECONOMIC IMPORTANCE OF USE

OF PESTICIDES IN WHEAT PRODUCTION . . . . . . . . . . . 1323

2. Berhe Gebregewergs, Muuz Hadush

DOES CLIMATE CHANGE AFFECT PRICE OF VEGETABLES:

EVIDENCE FROM TIGRAI, NORTHERN MOST ETHIOPIA. . . . .1335

3. Grujica Vico, Aleksandra Govedarica-Lučić, Zoran Rajić, Radomir Bodiroga, Ivan Mičić, Silvija Zec Sambol, Marija Mičić

MULTI ATTRIBUTE ASSESSMENT APPROACH

IN VEGETABLE PRODUCTION . . . . . . . . . . . . . . 1355

4. Igor Trandafilović, Vesna Conić, Aleksandra Blagojević

IMPACT OF DEMOGRAPHIC FACTORS ON

ENVIRONMENTALLY CONSCIOUS PURCHASE BEHAVIOUR. . .1365

5. Imre Milán Harcsa

STUDY ON THE POTENTIAL OF SUBCONTRACT

PALINKA DISTILLATION . . . . . . . . . . . . . . 1379

6. Jelena Andrašić, Vera Mirović, Nada Milenković, Branimir Kalaš, Miloš Pjanić

IMPACT OF TAKEOVER PROCESS ON EMPLOYEES -

EVIDENCE FROM FOOD, RETAIL AND FINANCIAL SECTOR . . .1393

7. Jelena Birovljev, Danilo Đokić, Bojan Matkovski, Žana Kleut

ECONOMIC PERFORMANCES OF AGRICULTURE

OF CEFTA AND FORMER CEFTA COUNTRIES . . . . . . . . . . 1413

8. Jelena Marković, Svetlana Stevović

SUSTAINABILITY OF CHEMICAL SOIL QUALITY

IN SOUTHERN MORAVA RIVER VALLEY

IN CORELLATION WITH THE FLOODING $\ldots \ldots \ldots \ldots \ldots$ 
9. Mile Peševski, Zoran Milovančević

THE CHANGES IN THE USAGE OF AGRICULTURAL LAND

IN EASTERN REGION OF REPUBLIC OF MACEDONIA

BETWEEN $1991-2030 \ldots \ldots$. . . . . . . . . . . . . . . . . . . . . . .

10. Odjuvwuederhie Emmanuel Inoni, 'Oraye Dicta Ogisi, Felix Odemero Achoja

PROFITABILITY AND TECHNICAL EFFICIENCY IN HOMESTEAD

CATFISH PRODUCTION IN DELTA STATE, NIGERIA . . . . . . . 1449

11. Olja Munitlak - Ivanović, Jovan Zubović, Petar Mitić

RELATIONSHIP BETWEEN SUSTAINABLE DEVELOPMENT AND

GREEN ECONOMY - EMPHASIS ON GREEN FINANCE

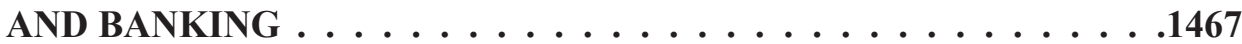

12. Petar Munćan, Dragica Božić

FARM SIZE AS A FACTOR OF EMLOYMENT AND INCOME

OF MEMBERS OF FAMILY FARMS . . . . . . . . . . . . . 1483

13. Rade Popović, Mira Kovljenić

EFFICIENCY OF WHEAT PRODUCTION ON FARMS

IN THE REPUBLIC OF SERBIA . . . . . . . . . . . . . . . . . . . . . . . . .

14. Radovan Damnjanović, Snežana Krstić, Milena Knežević, Svetislav Stanković,

Dejan Jeremić

THE DISCRIMINANT ANALYSIS APPLIED TO THE

DIFFERENTIATION OF SOIL TYPES . . . . . . . . . . . . 1513

15. Slavica Otović, Dunja Demirović, Kristina Košić, Aleksandra Vujko

FOSTERING ENTERPRENUERSHIP AT HIGH SCHOOLS:

A CASE OF RURAL AREAS IN VOJVODINA (SERBIA) . . . . . . .1523

16. Vladimir Ilić, Ivan Bauer, Anastazija Tanja Đelić, Aleksandar Nešković

INSTITUTIONAL SUPPORT FOR STRENGTHENING

ENTREPRENEURSHIP IN AGRICULTURAL PRODUCTION

OF THE REPUBLIC OF SERBIA . . . . . . . . . . . . . . . . . . . . . . . .

17. Boro Krstić, Zorica Vasiljević, Miroslav Nedeljković

INSURANCE CONTRACT AS THE BASIS FOR THE SAFETY OF

AGRICULTURAL PRODUCERS IN THE REPUBLIC OF SRPSKA • . 1555

18. Dejan Sekulić, Aleksandar Petrović, Vladimir Dimitrijević

WHO ARE WINE TOURISTS? AN EMPIRICAL INVESTIGATION

OF SEGMENTS IN SERBIAN WINE TOURISM . . . . . . . . . . . . . 
19. Milan Beslać, Ćorić Goran

FINANCIAL AND PRODUCTION ASPECTS OF GENETICALLY MODIFIED ORGANISMS $\ldots \ldots \ldots \ldots \ldots \ldots \ldots \ldots \ldots$

20. Mlađan Maksimović, Darjan Karabašević, Miodrag Brzaković, Pavle Brzaković THE EFFECTS RESULTING FROM THE APPLICATION OF THE CONCEPT OF THE SUSTAINABLE DEVELOPMENT OF RURAL TOURISM ON STARA PLANINA . . . . . . . . . . . . . . . .1595

21. Vesna Popović, Predrag Vuković, Milivoje Ćosić FOOD SAFETY AND QUALITY POLICY IN THE REPUBLIC OF SERBIA . . . . . . . . . . . . . . . . 1607

22. Radovan Pejanović, Danica Glavaš-Trbić, Mirela Tomaš-Simin PROBLEMS OF AGRICULTURAL AND RURAL DEVELOPMENT IN SERBIA AND NECESSITY OF NEW AGRICULTURAL POLICY . . . .1619

23. Saša Marković, Slavoljub Vujović, Aleksandar Damnjanović MARKETING AND HIGHER EDUCATION CONDITION IN SERBIA . . . . . . . . . . . . . . . . 1635

24. Semir Vehapi, Marina Milanović THE EFFECT OF MARKET ORIENTATION ON BUSINESS PERFORMANCE OF SERBIAN ORGANIC PRODUCERS . . . . . 1651

25. Suad Bećirović, Šemsudin Plojović, Enis Ujkanović, Senadin Plojović CHALLENGES AT STARTING AN AGRIBUSINESS IN THE HILLY MOUNTAINOUS REGIONS OF SOUTHWEST SERBIA . . . . . . . .1669

26. Vladimir Zakić, Vlado Kovačević, Jelena Damnjanović SIGNIFICANCE OF FINACIAL LITERACY FOR THE AGRICULTURAL HOLDINGS IN SERBIA . . . . . . . . . . 1687

27. Željko Bjelajac, Marijana Dukić Mijatović, Željko Vojinović PROTECTION OF LAND IN THE REPUBLIC OF SERBIA AND ECOLOGICAL SECURITY WITH REGARD TO STRATEGIC AND LEGAL FRAMEWORKS . . . . . . . . . .1703 